\title{
Variations in growth rates of cage cultured Asian seabass Lates calcarifer (Bloch, 1790) and cobia Rachycentron canadum (Linnaeus, 1766) in relation to environmental quality of marine farm at Karwar, India
}

\author{
JAYASREE LOKA, K. K. PHILIPOSE, N. G. VAIDYA, S. M. SONALI AND PRAVEEN DUBE \\ Karwar Research Centre of ICAR-Central Marine Fisheries Research Institute, Karwar - 581301 \\ Karnataka, India \\ e-mail:lokasree@gmail.com
}

\begin{abstract}
Growth rates of cage cultured Asian seabass Lates calcarifer (Bloch, 1790) and cobia Rachycentron canadum (Linnaeus, 1766 ) in relation to the water and sediment quality of marine farm at Karwar for two consecutive crops (2012-13 and 2013-14) were analysed. No significant variation was observed in the specific growth rate (SGR) of both the species between the crops. But within a crop, variations were observed in the SGR and absolute growth rate (AGR) of both the species $(\mathrm{p}<0.05)$. Specific growth rate of cobia was 0.75 and $0.78 \%$ day $^{-1}$ in 210 days of culture for the years 2012-13 and 2013-14 respectively. Physico-chemical parameters of water at cage and reference sites did not vary significantly, except for ammonia-nitrogen and nitrate-nitrogen levels at cage site between and within the crops. No significant variation was observed in total bacterial and Vibrio loads of water in cage site between the crops but significant variation was observed within the crop. The results revealed that temperature $(r=+0.61$ for $2012-13$ and +0.63 for 2013-14) and salinity $(r=+0.6$ for $2012-13$ and +0.5 for 2013-14) played a major role on SGR of cobia during both the crops with higher AGR recorded during summer months. In case of Asian seabass, no significant impact of temperature and salinity on SGR was noticed during the experimental period.

Keywords: Asian seabass, Cage culture, Cobia, Environmental quality, Growth rate, Lates calcarifer, Rachycentron canadum
\end{abstract}

Cage farming of marine finfish is expanding rapidly all over the world due to high demand of fish in international market and also as an alternate livelihood for the fishermen community. In recent years, marine finfish like cobia, pompano, snappers and breams are increasingly being used for large scale cage culture, due to their rapid growth and versatility to marine cage farming and also due to their disease resistance. Several reports are available on cage culture and the growth performance of these species (Kelly and Arnold, 1999, Watanabe et al., 2001; Liao et al., 2004; Sun et al., 2006 a, b, c; Zhou et al., 2006; Benetti et al., 2002, 2008, 2010; Philipose et al., 2013a, b). Water quality is considered as an important factor for the growth and production of cage cultured fish, as it influences the health of the environment as well as the fish (Wu, 1995; Bjornsson et al., 2007; Sun and Chen, 2014). Significant effect of water temperature and salinity on the growth of cage cultured fish has been reported by several workers (Faulk and Holt, 2006; Zhou et al. 2006; Yu and Ueng 2007; Sun et al., 2006 a, b, c, 2009; Chen et al., 2009). However, in India, very little information is available on environmental health status of the cage site and its impact on fish growth (Prema et al., 2010; Philipose et al., 2012).

The present study assessed the growth of Asian seabass Lates calcarifer (Bloch, 1790) and cobia Rachycentron canadum (Linnaeus, 1766) in relation to water and sediment quality of the cage farm, during two consecutive crops (210 days of culture for each crop), in 2012-13 and 2013-14. The investigation was carried out in the marine cage farm of the Karwar Research Centre of ICAR-Central Marine Fisheries Research Institute (14049'914'N; 7406'002”E), along the south-west coast of India. Reference site was selected 500 $\mathrm{m}$ away from the cage site towards south. Hatchery reared fingerlings of cobia and Asian seabass were stocked in $6 \mathrm{~m}$ dia floating steel cages at a density of 4 and 14 nos. $\mathrm{m}^{-3}$ respectively. Initial average weights of cobia and seabass fingerlings were 30 and $20 \mathrm{~g}$ respectively. All the fish were fed with fresh chopped oilsardine (Sardinella longiceps) @ $6 \%$ of total biomass twice a day. Growth in terms of weight (g) of cobia and Asian seabass was monitored at monthly intervals by random sampling of 20 nos. of fish and the growth rate was analysed by calculating specific growth rate (SGR) and absolute growth rate (AGR) using the formulae:

$$
\begin{aligned}
& \operatorname{SGR}\left(\% \text { day }^{-1}\right)=100^{*}(\ln \mathrm{W} 2-\ln \mathrm{W} 1) /(\mathrm{t} 2-\mathrm{t} 1) \\
& \operatorname{AGR}\left(\mathrm{g} \mathrm{day}^{-1}\right)=(\mathrm{W} 1-\mathrm{W} 2) /(\mathrm{t} 2-\mathrm{t} 1)
\end{aligned}
$$

For assessment of water quality, samples were collected from the cage and reference sites. Water quality parameters such as temperature, salinity, $\mathrm{pH}$ and dissolved oxygen (DO), 
were analysed using portable thermometer, refractometer, DO meter (YSI) and $\mathrm{pH}$ meter (Merck) respectively. Ammonia-nitrogen, nitrite-nitrogen, nitrate-nitrogen and bacterial loads were analysed at weekly intervals following standard procedures (APHA, 2004). Sediment samples from cage and reference sites were collected with Van Veen grab and was analysed for total bacterial and total Vibrio counts following standard methods (APHA, 2004). Both water and sediment samples were collected at the same time, at monthly intervals during the culture period. To understand the impact of water quality on the growth rate of fish, data were subjected to analysis of variance (one way and two way ANOVA) and correlation analysis.

The average weight of cobia recorded at the time of harvest after 210 days of experimental farming conducted during 2012-13 and 2013-14, were 1.24 and $1.19 \mathrm{~kg}$ respectively, while for seabass, it was 0.48 and $0.53 \mathrm{~kg}$ respectively. Specific growth rate recorded for cobia was 0.75 and $0.78 \%$ day $^{-1}$ in 210 days of culture, for the years 2012-13 and 2013-14 respectively. Absolute growth rate of cobia was found to be more during summer months. Monthly variations in the SGR of cobia and Asian seabass are shown in Fig. 1 and 2 respectively. Between the crops there was no significant variation in SGR of both the species but, between the months within a crop, variations in SGR and AGR were observed $(p<0.05)$ for both cobia and Asian seabass.

The physico-chemical parameters of water at cage site recorded during the culture period in the two consecutive years are presented in Fig. 3(a-g). The water quality parameters of cage and reference sites were within the optimum levels and no significant variation in the levels were observed. At the cage site, water temperature varied between $26.4-32^{\circ} \mathrm{C}$ during 2012-13 and between $28 \cdot 1-31.1^{\circ} \mathrm{C}$ during 2013-14. Salinity values varied between $25-33$ and 27-33 ppt for the periods 2012-13 and 2013-14 respectively. The dissolved oxygen of water at cage site during 2012-13 ranged between 3.1-4.5 $\mathrm{mg} \mathrm{l}^{-1}$

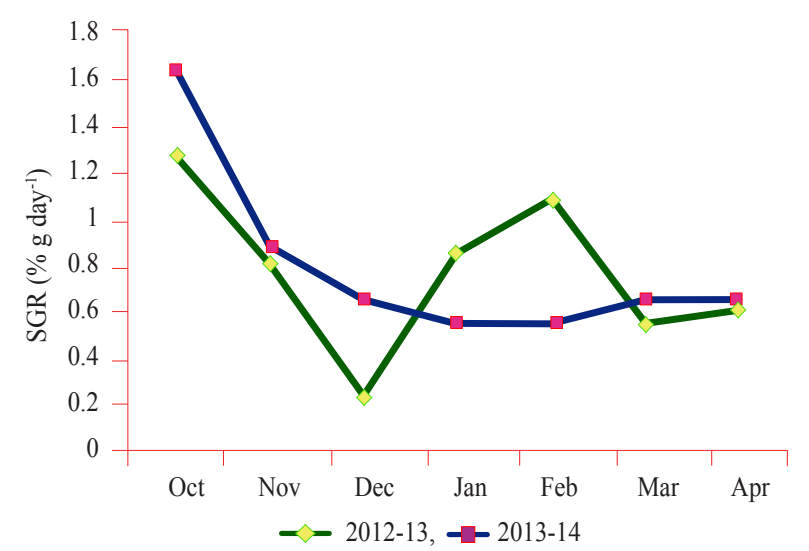

Fig. 1. Specific growth rate $\left(\% \mathrm{~g}_{\text {day }}{ }^{-1}\right)$ of $R$. canadum cultured in marine cage farm

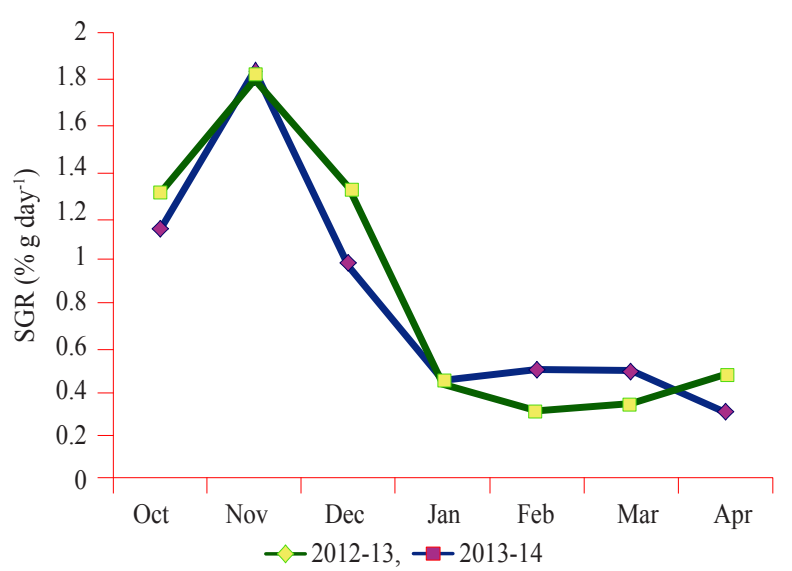

Fig. 2. Specific growth rate $\left(\% \mathrm{~g} \mathrm{day}^{-1}\right)$ of $L$. calcarifer cultured in marine cage farm

and the values varied between 3.4 - $6.6 \mathrm{mg} \mathrm{l}^{-1}$ during 2013-14. The ammonia-nitrogen levels in water at cage site were between 0.01-0.05 $\mathrm{mg} \mathrm{l}^{-1}$ during both the years. A significant variation was observed in the ammonia-nitrogen and nitrate-nitrogen values between and within the crops $(\mathrm{p}<0.05)$ whereas, the other physico-chemical parameters of water did not show any variation between or within the crops.

Total bacterial counts of water at cage site ranged between $1.8 \times 10^{4}$ to $3.2 \times 10^{6} \mathrm{cfu} \mathrm{m}^{-1}$ during 2012-13 and between $0.3 \times 10^{4}$ to $1.1 \times 10^{6} \mathrm{cfu} \mathrm{ml}^{-1}$ during 2013-14. Total Vibrio loads of water at cage site recorded were in the range $0.2 \times 10^{1}-1.3 \times 10^{3} \mathrm{cfu} \mathrm{m}^{-1}$ in the year 2012-13 and $0.8 \times 10^{2}$ - $0.7 \times 10^{3} \mathrm{cfu} \mathrm{m}^{-1}$ during the year 2013-14. During March 2014, the total Vibrio load of water was found to be high, in both cage and reference sites. Veronica and Julian (2013) reported mortality of cage cultured fish during the periods of high water temperature and they also recorded high density of Vibrio bacteria in column waters and they mentioned that the water temperature enhances the susceptibility of cultured marine fish species to Vibrio infections. In the present study also, a positive correlation was observed between temperature and total Vibrio loads of water during both culture periods in 2012-13 $(\mathrm{r}=0.64)$ and $2013-14(\mathrm{r}=0.52)$, but no Vibrio infections were recorded in cobia or Asian seabass during the experimental farming.

No significant variation was recorded in the temperature and $\mathrm{pH}$ values of sediment between the cage and reference sites. Total bacterial counts of sediment at cage site ranged between $0.5 \times 10^{3}$ to $1.4 \times 10^{6} \mathrm{cfu} \mathrm{g}^{-1}$ during 2012-13 and between $0.42 \times 10^{4}$ to $1.9 \times 10^{8} \mathrm{cfu} \mathrm{g}^{-1}$ during 2013-14. Total Vibrio loads of sediment at cage site ranged between $0.4 \times 10^{2}$ to $0.8 \times 10^{4} \mathrm{cfu} \mathrm{g}^{-1}$ and $1.2 \times 10^{2}$ to $2.32 \times 10^{4} \mathrm{cfu} \mathrm{g}^{-1}$ for the years 2012-13 and 2013-14 respectively. Significant variation $(\mathrm{p}<0.05)$ was observed in the total bacterial count and total Vibrio counts of sediment between the cage and reference sites. Physico-chemical parameters of water and sediment 


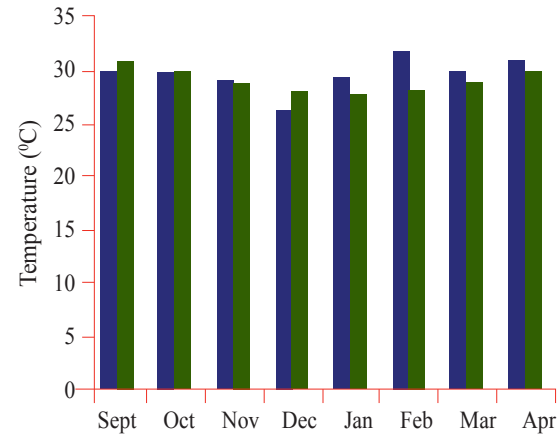

(a)

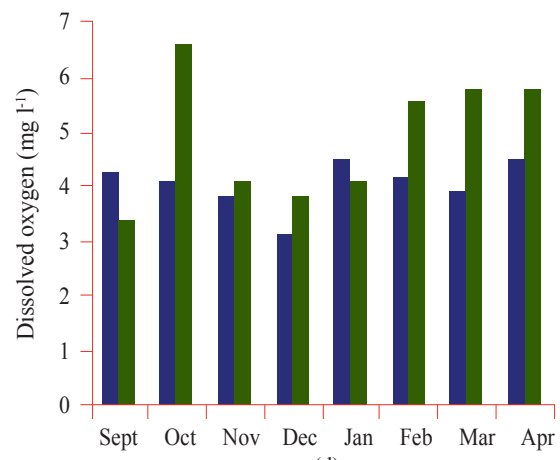

(d)

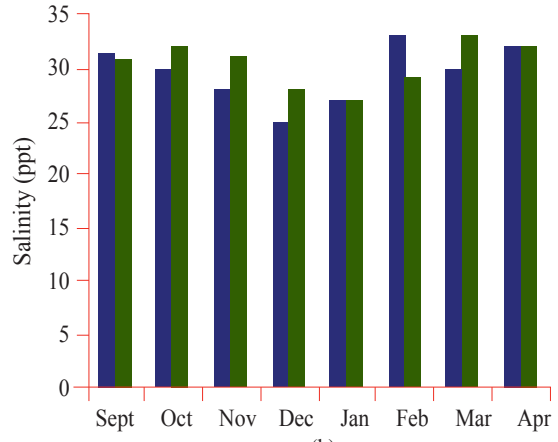

(b)
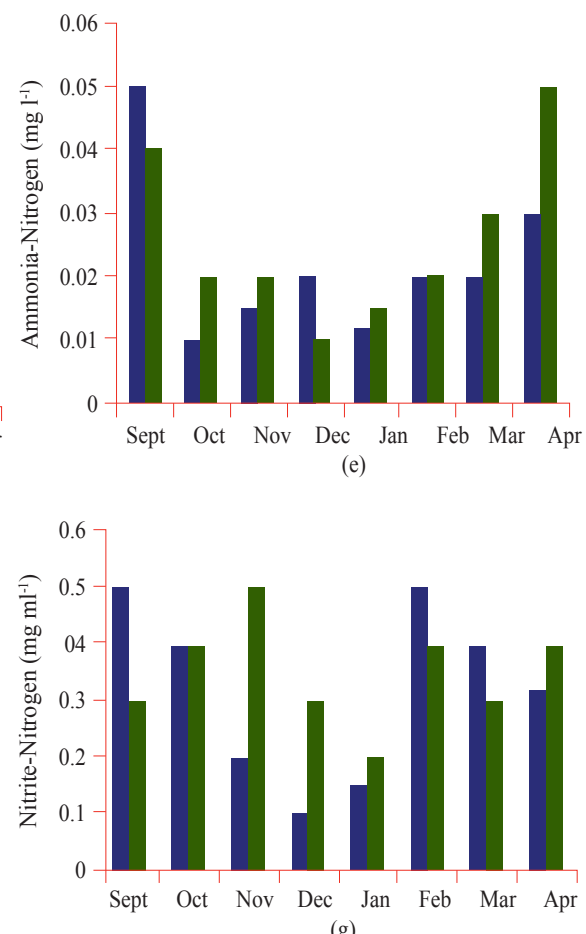
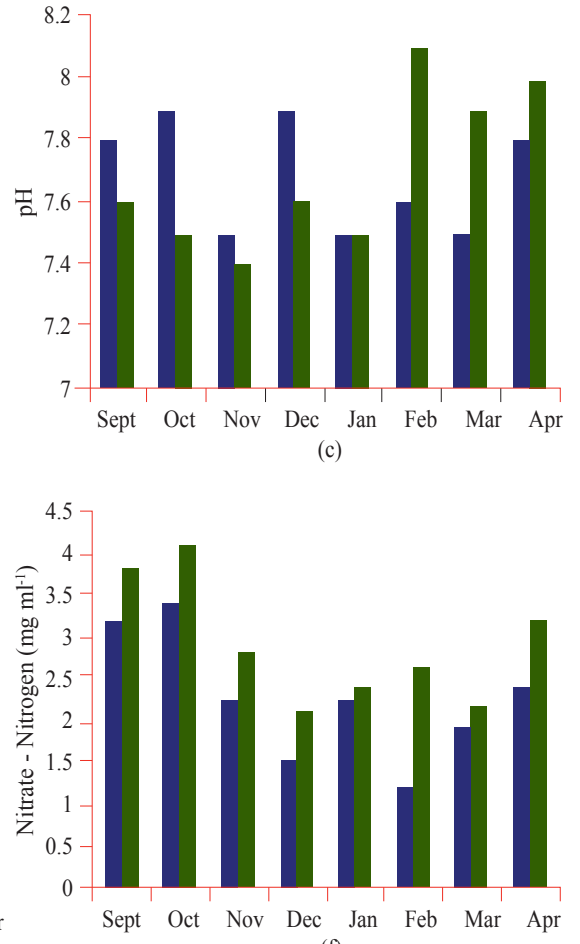

Fig. 3. Water quality parameters at cage site during the culture period. a) Temperature, b) Salinity, c) pH, d) Dissloved oxygen, e) Ammonia-nitrogen, f) Nitrate-nitrogen, g) Nitrite-nitrogen

influence the density of Vibrio loads in the cage site, which may cause variations in the growth rate as well as the health of fish.

Results of the study revealed that temperature $(\mathrm{r}=+0.61$ for 2012-13 and +0.63 for 2013-14) and salinity $(r=+0.6$ for 2012-13 and +0.5 for 2013-14) played a major role on the growth rate of cobia during both the crops, but no influence of temperature was recorded on the SGR of Asian seabass during the present study (Fig. 4a, b; Fig. 5a, b). It was also observed that ammonia levels had a negative impact on the growth rate of cobia during both the years $(r=-0.62$ for 2012-13 and -0.51 for 2013-14) (Fig. 6 a, b).

The study revealed no significant variation in the water and sediment quality between cage and reference sites, indicating healthy environmental conditions in the cage site. The analyses on the impact of water quality parameters on fish growth revealed that the growth rate of Asian seabass was not affected by temperature, salinity, dissolved oxygen and ammonia-nitrogen levels, during both the culture periods. However, it was observed that temperature played a major role on the growth rate of cobia $(r=+0.61$ for $2012-13$ and +0.63 for 2013-14) during both crops. A strong, positive linear relationship between water temperature and growth rate was reported by Yu and Ueng (2007) as well as by Lanier and Scharf (2007) and they observed that the combined effect of water temperature, salinity and dissolved oxygen contributed towards $60 \%$ of the variance in observed growth. The present study also recorded higher growth rates during the months of March and April, when the water temperature and salinity were at higher levels contradicting the 


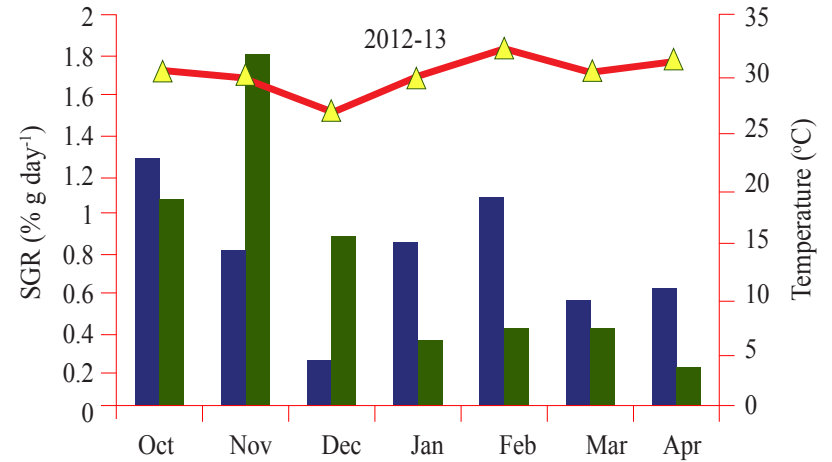

(a)

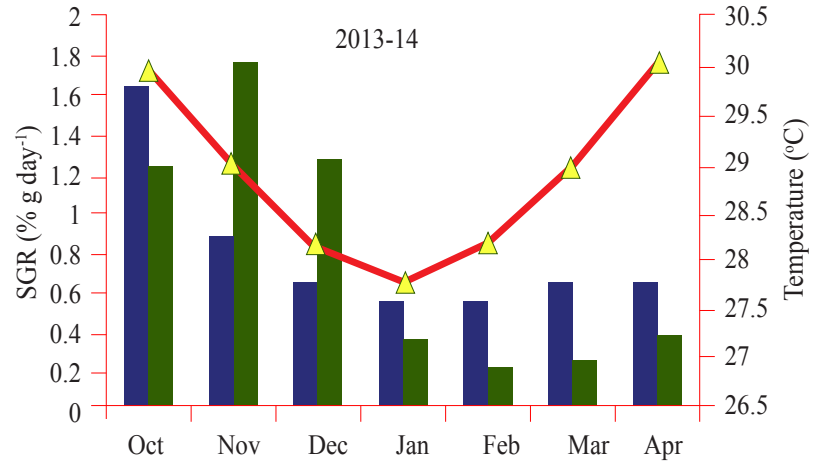

(b)

Fig. 4. Monthly specific growth rate (SGR) of $R$. canadum and L. calcarifer in relation to water temperature $\left({ }^{\circ} \mathrm{C}\right)$ during a) 2012-13; b) $2013-14$

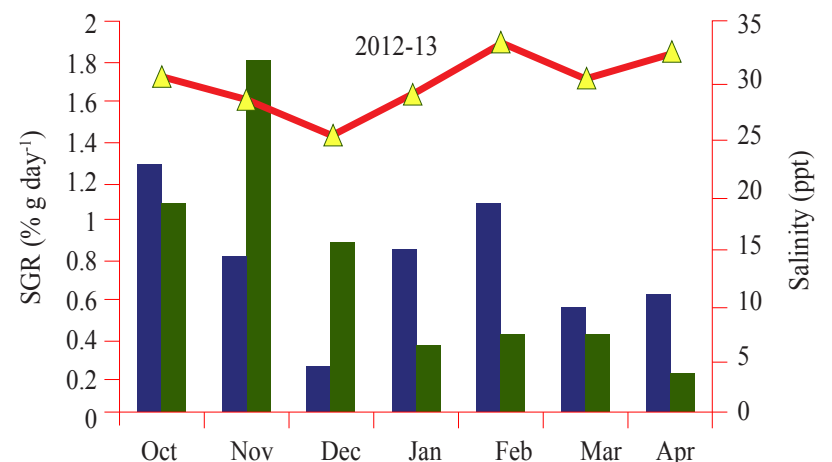

(a)

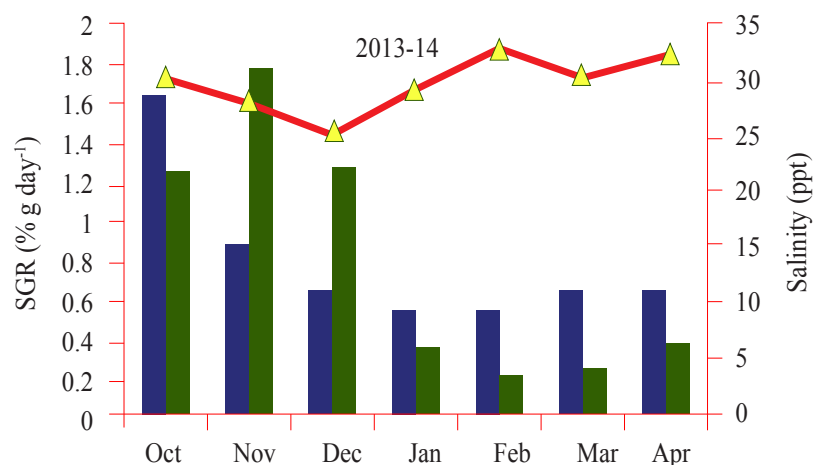

(b)

Fig. 5. Monthly specific growth rate (SGR) of $R$. canadum and L. calcarifer in relation to water salinity (ppt) during a) 2012-13; b) 2013-14

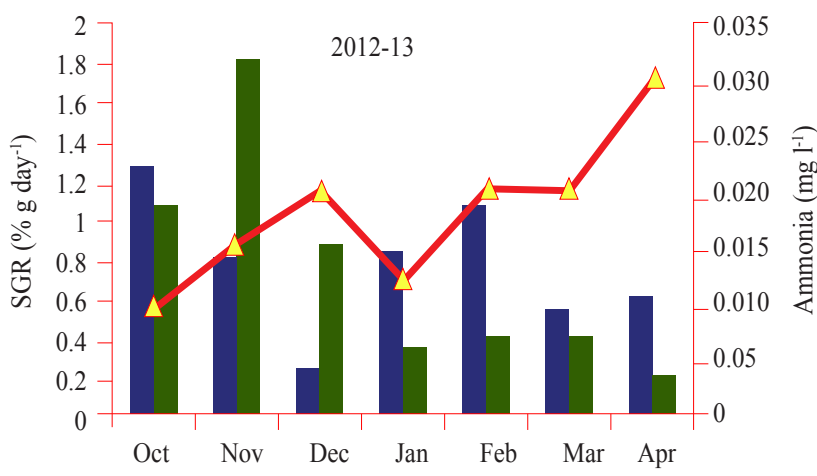

(a)

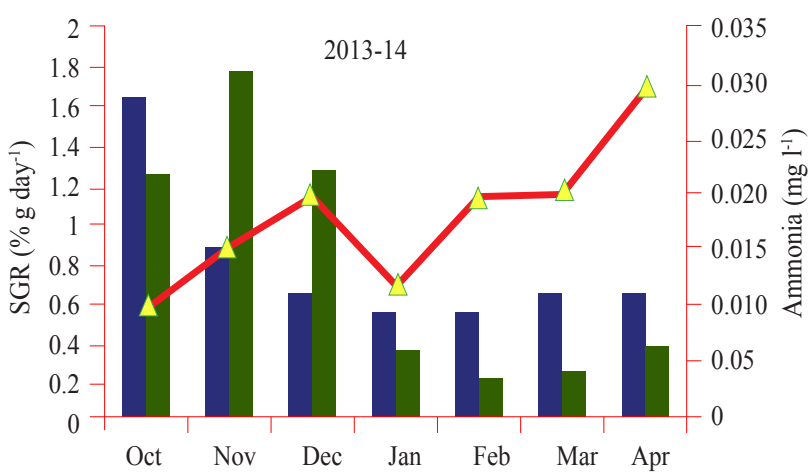

(b)

Fig. 6. Monthly specific growth rate (SGR) of $R$. canadum and L. calcarifer in relation to water ammonia levels (mg $\left.1^{-1}\right)$ during a) $2012-13$; b) 2013-14

observations by Sun and Chen (2009) who reported poor growth of cobia fingerlings in indoor tanks at higher temperature range of $23-35^{\circ} \mathrm{C}$.

Environmental impact assessment and monitoring is an important aspect of cage farming in marine waters, as it ensures the environmental sustainability of marine cage farming. The impact on environmental quality can be reduced significantly by careful site selection, proper management of stocking density, feed formulation and integrated approach of culture systems (Wu, 1995). The present study apparently 
showed decreased levels of dissolved oxygen and increased ammonia levels in the column and bottom waters at cage site compared to reference site, but were found statistically insignificant. Similar results were recorded on dissolved oxygen depletion in water column in the marine fish farms (Bergheim et al., 1982; Penczak et al., 1982; Beveridge, 1985; Enell, 1987). The present study also revealed a positive correlation in the growth rate of cobia with higher saline conditions during summer months, but no such correlation was observed in the case of Asian seabass. In contrary, higher growth and feed conversion efficiency in Atlantic halibut were recorded by Imsland et al. (2008) at 16 ppt salinity. $\mathrm{Wu}$ (1995) emphasised the importance of environmental impact assessment (EIA) for sustainable development of mariculture industry. In conclusion, the present investigation revealed that the growth rate of cage cultured fish was influenced by fluctuations in water temperature and salinity but largely specific to the species cultured. The study suggested that cage culture of cobia during summer months and harvest of crop in the early monsoon can yield higher growth rate and production.

\section{Acknowledgements}

Authors are thankful to the Director, ICAR-Central Marine Fisheries Research Institute, Kochi, India for providing facilities to carry out this work.

\section{References}

APHA 2004. Standard methods for the examination of water and waste water, $15^{\text {th }}$ edn. American Public Health Association, Washington DC, $1134 \mathrm{pp}$.

Benetti, D. D., Matera, J. A., Feeley, M. W., Stevens, O., Alarcon, J. F., Banner-Stevens, G., Minemoto, Y., O'Hanlon, B. and Eldridge, L. 2002. Growth, survival and feed conversion rates of hatchery reared mutton snapper Lutjanus analis raised in floating net cages. J. World Aquac. Soc., 33: 349-357.

Benetti, D. D., Orhun, M. R., Sardenberg, B., O'Hanlon, B., Welch, A., Hoenig, R., Zink, I., Rivera, J. A., Denlinger, B., Bacoat, D., Palmer, K. and Cavalin, F. 2008. Advances in hatchery and grow-out technology of cobia Rachycentron canadum (Linnaeus). Aquac. Res., 39: 701-711.

Benetti, D. D., O'Hanlon, B., Rivera, J. A., Welch, A. W., Maxey, C. and Orhun, M. R. 2010. Growth rates of cobia (Rachycentron canadum) cultured in open ocean submerged cages in the Caribbean. Aquaculture, 302: 195-201.

Bergheim, A., Hustveit, H., Kittelsen, A. and Selmer-Olsen, A. 1982. Estimated pollution loadings from Norwegian fish farms, I. Investigation 1978-79. Aquaculture, 28: 346-361.

Beveridge, M. C. M. 1985. Cage and pen fish farming: carrying capacity models and environmental impact. FAO Fisheries Technical Paper, 255: 1-131.
Bjornsson, B., Steinarsson, A. and Arnason, T. 2007. Growth model for Atlantic cod (Gadus morhua): Effects of temperature and body weight on growth rate. Aquaculture, 271: 216-226.

Chen, G., Wang, Z., Wu, Z. and Binhe, G. U. 2009. Effects of salinity on growth and energy budget of juvenile cobia, Rachycentron canadum. J. World Aquac. Soc., 40: 374-382.

Enell, M. 1987. Environmental impact of cage fish farming with special reference to phosphorus and nitrogen loadings. International Council for Exploration of Sea, Copenhagen, Denmark. ICES Mariculture Committee, 1987/F44, 13pp.

Faulk, C. K. and Holt, G. J. 2006. Response of cobia Rachycentron canadum larvae to abrupt or gradual changes in salinity. Aquaculture, 254: 275-283.

Imsland, A. K., Gustavsson, A., Gunnarsson, S., Foss, A., Arnason, J., Jonsson, A. F., Smaradottir, H., Arnarson, I. and Thorarensen, H. 2008. Effects of reduced salinities on growth, feed conversion efficiency and blood physiology of juvenile Atlantic halibut (Hippoglossus hippoglossus L.). Aquaculture, 274: 254-259.

Lanier, J. M. and Scharf, F. S. 2007. Experimental investigation of spatial and temporal variation in estuarine growth of age 0 juvenile red drum (Sciaenops ocellatus). J. Exp. Mar. Biol. Ecol., 349: 131-141.

Kelly, J. L. and Arnold, D. E. 1999. Effects of ration and temperature on growth of age-0 Atlantic white sturgeon. N. Amer. J. Aquac., 61: 51-57.

Liao, I., Huang, T., TsaI, W., Hsueh, C., Chang, S. and Leano, E. M. 2004. Cobia culture in Taiwan: current status and problems. Aquaculture, 237: 155-165.

Penczak, T., Galicka, W., Molinski, M., Kusto, E. and Zalewski, M. 1982. The enrichment of a mesotrophic lake by carbon, phosphorous and nitrogen from the cage aquaculture of rainbow trout. Salmo gairdneri. J. Appl. Ecol., 19: 371-393.

Philipose, K. K., Krupesha Sharma, S. R., Jayasree Loka, Divu, D., Syda Rao G. S., Vaidya, N. G., Sonali S. M., Sadhu, N. and Dube, P. 2012. Observations on variations in physico-chemical water parameters of marine fish cage farm off Karwar. Indian J. Fish., 59(1): 83-88.

Philipose, K. K., Jayasree Loka, Krupesha Sharma, S. R., Divu, D., Srinivasa Rao, K., Sadhu, N., Dube, P., Gopakumar, G. and Syda Rao, G. 2013a. Farming of Cobia, Rachycentron canadum (Linnaeus 1766) in open sea floating cages in India. Indian J. Fish., 60(4): 35-40.

Philipose, K. K., Krupesha Sharma, S. R., Jayasree Loka, Divu, D., Sadhu, N. and Dube, P. 2013b. Culture of Asian seabass (Lates calcarifer, Bloch) in open sea floating net cages off Karwar, south India. Indian J. Fish., 60(1): 67-70.

Prema, D., Sobhana, K. S., Laxminarayana, A., Imelda Joseph, Shoji Joseph, Boby Ignatus, Jeyabaskaran, R., Nandakumar, A., Khambadkar, L. R., Anilkumar, P. S., Shylaja, G. and Syda Rao, G. 2010. Observations on selected characteristics of 
water and sediment at the open sea cage culture site of Asian seabass Lates calcarifer (Bloch) off Cochin, south-west coast of India. Indian J. Fish., 57(4): 53-59.

Sun, L. H. and Chen, H. R. 2009. Effects of ration and temperature on growth and energy budget of juvenile cobia (Rachycentron canadum). Aquaculture, 292: 197-206.

Sun, L. and Chen, H. 2014. Effects of water temperature and fish size on growth and bioenergetics of cobia (Rachycentron canadum). Aquaculture, 426\&427: 172-180.

Sun, L. H., Chen, H. R. and Huang, L. M., 2006a. Effect of temperature on growth and energy budget of juvenile cobia (Rachycentron canadum). Aquaculture, 261: 872-878.

Sun, L. H., Chen, H. R., Huang, L. M. and Wang, Z. D. 2006b. Growth, faecal production, nitrogenous excretion and energy budget of juvenile cobia (Rachycentron canadum) relative to feed type and ration level. Aquaculture, 259: 211-221.

Sun, L. H., Chen, H. R., Huang, L. M., Wang, Z. D. and Yan, Y. 2006c. Growth and energy budget of juvenile cobia
(Rachycentron canadum) relative to ration. Aquaculture, 257: 214-220.

Watanabe, W. O, Ellis, S. C. and Chaves, J. 2001. Effects of dietary lipid and energy to protein ratio on growth and feed utilisation of juvenile mutton snapper (Lutjanus analis) fed isonitrogenous diets at two temperatures. J. World Aquac. Soc., 31: 29-40.

Wu, R. S. S. 1995. The environmental impact of marine fish culture: towards a sustainable future. Mar. Poll. Bull., 31 (4-12): 159-166.

Yu, S. L. and Ueng, P. S. 2007. Impact of water temperature on growth in cobia Rachycentron canadum, cultured in cages. Israeli J. Aquc., Bamidgeh., 59(1): 47-51.

Zhou, Q. C., Wu, Z. H., Tan, B. P., Chi, S. Y. and Yang, Q. H. 2006. Optimal dietary methionine requirement for juvenile Cobia (Rachycentron canadum). Aquaculture, 258: 551-557.

Veronica, A. and Julian, R. 2013. Effect of water temperature on susceptibility of cultured marine fish species to vibriosis. Int. J. Res. Pure Appl. Microbiol., 3(3): 48-52. 